\title{
The Impact of R\&D and ICT Investment on Innovation and Productivity in Chilean Firms
}

\author{
Autores: \\ Roberto Álvarez
}




\title{
The Impact of R\&D and ICT Investment on Innovation and Productivity in Chilean Firms
}

\author{
Roberto Álvarez \\ robalvar@fen.uchile.cl \\ University of Chile
}

\begin{abstract}
* $^{*}$
This paper examines the impact of information and communication technology (ICT) and research and development (R\&D) investment on innovation and productivity in Chilean firms, in particular those in the services industry. It provides new evidence on this topic for a developing country and also for firms in the services sector, areas in which existing evidence is limited. The findings for services industries are relevant because this sector in Latin America has a large productivity gap when compared to the sector in developed countries. The results show that ICT contributes positively to innovation and productivity in both the total sample and the services industry. They also confirm that ICT investment increases productivity directly and not only through innovation, suggesting that this investment would have additional effects on productivity.
\end{abstract}

JEL Codes: $\mathrm{O}_{31}, \mathrm{O}_{32}, \mathrm{D}_{22}$

Keywords: ICT, R\&D, innovation, productivity

* The author (Roberto Alvarez, University of Chile, robalvar@fen.uchile.cl) thanks the Inter-American Development Bank for funding this project, as well as Matteo Grazzi, Juan Miguel Gallego, and seminar attendants at the Economic Commission for Latin America and the Caribbean (ECLAC) and Del Rosario University (Colombia) for their valuable comments and suggestions, and Damián Vergara for his diligent research assistance. 


\section{Introduction}

The adoption of information and communication technologies (ICT) is a pervasive phenomenon in developed countries and of growing importance for developing countries. Since Solow (1987) wrote his article, there has been a huge debate on the impact of ICT on economic performance and, particularly, on productivity. For example, Acemoglu et al. (2014) present novel evidence that casts doubts on the positive association between ICT and productivity in the United States. However, in general, previous microeconomic evidence for several countries-in particular developed ones—shows that ICT might be an important driver of productivity. Most firm-level studies in this literature show that investment in ICT is positively correlated with productivity (Black and Lynch, 2001; Bresnahan, Brynjolfsson, and Hitt, 2002; Bugamelli and Pagano, 2004ii Greenan and Mairesse, 2000)ํ․

There is also some evidence that ICT may facilitate innovation and, through this mechanism, affect productivity indirectly. Several studies find that ICT tends to be positively associated with different indicators of innovation, such as product, process, and organizational innovations (Hempell and Zwick, 2008; Higón, 2012; Koellinger, 2008; Morikawa; 2004). Some authors also examine the complementary effects between ICT and other firm characteristics. In particular, Black and Lynch (2001) and Bresnahan, Brynjolfsson, and Hitt (2002) analyze the interactions among ICT, human capital, and organizational change.

More recently, Hall, Lotti, and Mairesse (2013) and Polder et al. (2009) explore the joint impact of research and development (R\&D) and ICT investments on innovation and productivity. Hall, Lotti, and Mairesse (2013) study Italian firms, showing that R\&D investment is more important for innovation than ICT investment, while ICT is more important than R\&D for productivity. Polder et al. (2009) examine Dutch firms, finding differential effects of both investments across industries. Their results

\footnotetext{
${ }^{1}$ See Cardona, Kretschmer, and Strobel (2013) for a recent survey of the literature.
} 
suggest that R\&D only contributes to innovation in manufacturing while ICT affects positively all types of innovation in services but not in manufacturing. According to these authors, the industry differences in the impact of R\&D and ICT are given by the fact that new ICT applications would be more relevant for firms in the services sector. The present study also analyzes empirically the importance of R\&D and ICT investment for innovation, focusing on the effects in a developing country context.

The evidence for developing countries in these issues is relatively scarce. Some exceptions are Aboal and Tacsir (2015) for Uruguay; Commander, Harrison, and Menezes-Filho (2011) for Brazil and India; and Gallego, Gutiérrez, and Lee (2014) for Colombia. The results in these papers are consistent with the idea that ICT relates positively with innovation and productivity, but they do not control for the impact of R\&D.

The current paper contributes to this literature in two main aspects. First, we provide novel evidence for a developing country on the relative importance of R\&D and ICT investment. This may have important policy implications for channeling public resources to enhance innovation and productivity in developing economies. Second, we look at differences across industries. In particular, we explore the impact of R\&D and ICT on innovation in the services industry. This provides an interesting setting because, although the services industry has gained importance in Latin America countries, productivity in this industry has grown slowly. There is a concern that this productivity slowdown will persist and the gap will increase (Pagés, 2010).

Our findings indicate that ICT contributes positively to innovation and productivity in both the total sample and the services industry. We also find that ICT investment increases productivity directly and not only through innovation. In sum, our results indicate that ICT has a potential to increase productivity in developing nations, particularly in the services industry.

The paper is structured as follows. In the second section, we describe the data. In the third section, we present the methodology and the identification assumption in a modified version of the CDM model 
(Crépon., Duguet and Mairesse, 1998). In section fourth and five, we show the results for all industries and the services sector, respectively. The sixth section concludes.

\section{Data}

The data for this empirical analysis come from the 2007 and 2009 Longitudinal Enterprises Survey (Encuesta Longitudinal de Empresas, or ELE) provided by the Chilean Ministry of Economy. The sample of the survey, corresponding to formal firms in the Chilean economy, was stratified according to industry (1-digit of ISIC classification), size (6 segments according to sales), and geographical localization (13 regions). The ELE has been designed as a panel, and we use the information for more than 2,300 firms that are present in both years.

Table 1 presents the total number of firms and the distribution across sectors. The retail and the manufacturing sectors have the highest distribution (23 percent and 13 percent, respectively), while financial services and utilities have the lowest ( 4 percent and 3 percent, respectively). Firms in the services sector represent 76 percent of the sample.

The ELE provides detailed information on firm characteristics; in particular it collects data for R\&D and ICT investments and innovation activities. The innovation surveys in Chile used in previous studies (Álvarez, Bravo-Ortega, and Navarro, 2010; Álvarez, Zahler, and Bravo-Ortega, 2010; Benavente, 2006; Crespi and Zúñiga, 2012) follow the Organisation for Economic Co-operation and Development (OECD) Oslo Manual and do not have information on ICT investment. With some minor changes between the two surveys, the ELE questionnaire has been structured according to the following 6 sections: accounting and financing, commercialization, management (including Innovation), human resources, and ICT.

Table 2 shows descriptive statistics of the variables relative to ICT and R\&D investment and innovations variables. ${ }^{2}$ About 29 percent of the firms in the sample invested in ICT. For firms in the

\footnotetext{
${ }^{2}$ The next section discusses the econometric specification and defines the variables used in the estimation.
} 
services sector, this percentage is slightly lower. However, conditional on investing, the firms in the service sector show a higher average ICT investment per worker. In contrast, very few firms invested in R\&D activities (2.2 percent). This is indeed lower for firms in the services sector (1.4 percent). In this case, conditional on investing in $R \& D$, the investment per worker is lower for the services sector compared with the total sample.

Table 2 reveals that about 45 percent of the firms have introduced some innovation, either technological or non-technological, and the figure is similar for firms in the service sector. In general, the incidence of technological innovation (41.6 percent) is higher than non-technological innovations (26.1 percent). This is true for the total sample and the services sectors. Finally, as one the main interest variable, we show the descriptive statistics for the measure of productivity used in this paper (sales per worker).Consistent with international evidence, there is a large heterogeneity in firms' productivity, and the average productivity is lower in the services sectors ( 86 percent).

Table 3 describes the explanatory variables used in the estimation. About 12 percent of firms are exporters, while 9.5 percent are likely to export. The percentage of foreign firms is 7.4 percent, very similar to what is found for firms in the services sector. In terms of public support for innovation activities, 17.3 of firms have received public funds for innovation, higher than the incidence in services (15.5 percent). Regarding human capital, the percentage of skilled workers is about 15 percent in the total sample and 17.1 percent in the services sector. In terms of employment, the average size is just over 200 workers for both samples, with less in the services sector than in the total sample. The percentage of firms doing on-line procedures is almost 86 percent. Finally, as expected, capital per worker is lower in services firms, about 38 percent of the capital per worker in the total sample. 


\section{Methodology}

Our main question is how ICT and R\&D investments affect innovation in Chilean firms. In the case of $R \& D$, it is widely documented that there is a close relationship between innovation and R\&D investment. ${ }^{3}$ In the case of ICT and innovation, the relationship between both variables has been explored more recently than the impact of $R \& D$ on innovation. Moreover, few papers have included both R\&D and ICT as determinants of innovation. Why does ICT investment affect innovation? Hall, Lotti and Mairesse (2013) discuss the denominated traditional and non-traditional arguments for incorporating ICT as a determinant of innovation. First, the traditional argument indicates that ICT investment enables innovation in business practices that lead to cost reductions and improved output. The non-traditional argument views ICT as a direct input for developing new ways of doing business and more modern goods and services.

To explore the role of R\&D and ICT as inputs for innovation, our methodology follows the empirical research line initiated by the influential work of Crépon, Duguet, and Mairesse (1998), who analyze the relationship between $R \& D$ investment, innovation outcomes, and firm productivity. This approach is based on a multi-equation model that takes into account the whole process of innovation, thereby considering the firms' decisions to invest in innovation, the results of these efforts, and their impact on productivity. Given that we are also interested in the impact of ICT investment, we extend this methodology by including the firms' decisions to invest in ICT in a similar way to the modeling of R\&D investment.

Following the CDM approach, our baseline model consists of a three-stage regression: (i) the firm's decision to invest in R\&D and the intensity of the investment in R\&D, ${ }^{4}$ as well as the firm's decision to invest in ICT and the intensity of the investment in ICT; (ii) the knowledge production function looking at

\footnotetext{
3 See Mairesse and Mohnen (2010) for a review of evidence using innovation surveys.

4 To be comparable with previous results using this methodology in developing countries, we have tried to use a specification for the R\&D equation that is similar to that employed by Crespi and Zúñiga (2012).
} 
the impact of and ICT intensity on innovation outcomes; and (iii) the output production function, in which firm productivity is a function of innovation outcomes and other control variables.

First, we estimate a generalized Tobit that considers the decision and amount to invest in R\&D and ICT. As previously discussed, the selection problem is particularly significant for R\&D given that only about 2 percent of the firms carry out this type of investment. Second, we use the predicted value of R\&D and ICT intensity as the explanatory variable in the knowledge production function, ${ }^{5}$ where the innovation outcome is measured by two alternative categorical variables that account for both technological and non-technological innovations. Finally, to analyze the impact of innovation on productivity, we use the predicted value of innovation outcomes as explanatory variables in the output production function. ${ }^{6}$ In this last stage, we use sales per worker as a proxy of productivity. Also, to determine whether ICT affects directly productivity, we include the predicted value of ICT investment in the output production function.

\subsection{R\&D and ICT Investment}

We rely on a generalized Tobit framework to model the decision and amount to invest in R\&D and ICT. Hence, there are two linked equations: (i) the decision to invest and (ii) the amount of resources involved. More precisely, we assume that there exists a latent dependent variable for firm i's investment effort, given by the following equation:

$$
I E_{i}^{*}=X_{1 i}^{\prime} \beta+\varepsilon_{i}
$$

5 We define R\&D and ICT intensity as R\&D and ICT investment per employee (both in logs).

${ }^{6}$ This model can be estimated using alternative econometric techniques as Asymptotic Least Squares, as estimated in the original paper by Crépon, Duguet, and Mairesse (1998). However, recent works on this issue prefer less computationally intensive techniques of estimation (Griffith at al., 2006; Hall Lotti, and Mairesse, 2009). 
where $X_{1 i}^{\prime}$ is a vector of explanatory variables, a vector of parameters, and an error term. The econometrician observes that resources are invested in R\&D activities $\left(I E_{i}\right)$ if $I E_{i}^{*}$ is positive or larger than a given threshold.

We assume the following selection equation describing whether a firm is investing or not:

$$
I D_{i}=1 \quad \text { if } \quad I D_{i}^{*}=W_{i}^{\prime} \alpha+e_{i}>c, \quad \text { and } 0 \text { otherwise. }
$$

where $I D$ is an observed binary variable equal to zero if a firm does not invest and 1 if it does invest, $I D_{i}^{*}$

is the corresponding latent variable such that a firm decides to invest if it is above a certain threshold denoted by $c$, and $W$ is a vector of explanatory variables. Conditional on investing, the observed investment $\left(I E_{i}\right)$ is given by:

$$
I E_{i}=\left(\begin{array}{l}
I E_{i}^{*}=Z_{i}^{\prime} \beta+\varepsilon_{i} \quad \text { if } I D_{i}=1 . \\
0 \quad \text { if } \quad I D_{i}=0 .
\end{array}\right)
$$

The system of equations (2) and (3) is estimated as a generalized Tobit model by maximum likelihood for both R\&D and ICT investments.

The vector of explanatory variables W and Z closely follows those used by Crespi and Zúñiga (2012). Therefore, we model the firm's decision to invest in R\&D and ICT considering the following explanatory variables: ${ }^{7}$

- Exporting: defined as dummy variable for exporters. This variable is used to capture the exposure to international markets that it is expected to increase R\&D and ICT investments through greater competition and learning effects.

\footnotetext{
7 Crespi and Zúñiga (2012) include a dummy variable for the utilization of patent protection to control for the capacity of the firm to manage intellectual property rights and its past stocks of knowledge, while the present survey does not contain information on this issue.
} 
- Firm size: defined as the number of workers (in logs). Firm size is expected to affect the probability of investment positively.

- Foreign ownership: defined as a dummy variable for foreign-owned firms. We expect a positive effect if foreign-owned firms can access technological information that it is not available to domestic firms.

The set of explanatory variables for R\&D intensity includes the corresponding variables defined above in addition to a variable measuring access to public financing for R\&D (public finance). This is defined as a dummy variable that indicates whether the firm uses public to fund R\&D investments. ${ }^{8}$

In the case of ICT investment, the equation system is similar to R\&D investment with some changes in the vector of explanatory variables that includes some specific determinants for this type of investment. The selection equation for ICT includes the following additional variables:

- Online: a dummy variable if the manager declares to have completed an online procedure. In this case, we expect that a higher demand for on-line activities-by, for example, clients or government agencies-will increase the probability of investing in ICT.

- ICT sector-region: the percentage of firms in the industry and region that invest in ICT. This is motivated by the literature suggesting that firms are more likely to adopt a new technology when other firms are doing the same. Basically, the idea is that there is reduction in the adoption cost.

The intensity equation for ICT also includes a human capital variable, defined as the share of skilled workers (with at least a college education). This type of investment is intensive in qualified workers (Bresnahan et al.2002), and thus we expect a positive impact of this variable on ICT.

The critical identification assumption on this methodology is the existence of some variables affecting the probability of investment in both R\&D and ICT, but not affecting the investment intensity.

\footnotetext{
${ }^{8}$ Additional control variables, such as cooperation for innovation and the importance of information sources for innovation, are not available in this survey.
} 
For both variables, size is utilized as exclusion restriction and is included in the selection equation only. In this case, we are assuming that size increases the probability of investing because there are fixed costs associated with the investment in new technologies. However, it does not affect the investment intensity, which is already expressed as per-worker.

In addition, for ICT investment and based on the idea of fixed costs of adoption, we include two other variables as exclusion restrictions: a dummy variable for online procedures and the percentage of firms in the sector and region that carry out investments in ICT. The first variable captures the impact of advances in technology, in particular in Internet connectivity access and speed, which have allowed firms to carry out more activities online (e.g., tax payments). The second variable is included because epidemiological models of technology adoption indicate that implementation is more likely when other agents are also taking advantage of these advancements.

\subsection{Innovation Production Function}

We construct two main indicators of innovation. As do several previous studies, the present study defines technological innovation as a dummy variable indicating if the firm declares having introduced either a product or process innovation. In the same way, we define non-technological innovation as a dummy variable indicating if the firm declares having introduced either a marketing or organizational innovation. Based on these indicators, we define a variable as "any innovation" if the firms introduces either technological or non-technological innovations.

We estimate separate probit models for both indicators: technological innovation and any innovation. These indicators are modeled as follows:

$$
\begin{aligned}
& T I=\delta R D I_{i}^{*}+\emptyset I C T I_{i}^{*}+\Pi Z_{i}+v_{i} \\
& A N Y=\vartheta R D I_{i}^{*}+\mu I C T I_{i}^{*}+\tau Z_{i}+\epsilon_{i}
\end{aligned}
$$

where $\mathrm{TI}(\mathrm{ANY}$ ) is equal to 1 whether the firm has introduced a technological (or any) innovation; $R D I^{*}$ is the predicted value of the firm R\&D investment (log of R\&D investment per worker); $I C T I^{*}$ is the 
predicted value of the firm ICT investment (log of innovation investment per worker) from the estimated generalized Tobit equations described above; and $\mathrm{Z}$ is a vector of additional explanatory variables.

This instrumental variable estimation, given by inclusion of predicted values of R\&D and ICT investments, takes into account the potential endogeneity of both variables. The estimation includes the following additional explanatory variables: (i) firm size, (ii) a dummy variable for exporting firms, (iii) a dummy variable for foreign-owned firms, and (iv) the percentage of firms that innovate in the same region and sector. This last variable is included based on the literature of the spillover effects of innovation. In the presence of technological spillovers, a higher presence of innovators should increase the firm's probability of introducing innovation (Feldman, 1999).

For this strategy to be valid, in addition to the inclusion of predicted values for R\&D and ICT investments in the innovation equation, we need to include variables that affect both investments but not innovation directly. In this case, as described above, we include a dummy variable for access to public support for financing R\&D projects. The assumption is that public financing affects investment, but not the probability of introducing innovations. Also, in the selection equations for the probability of R\&D and ICT investment, we have introduced variable affecting ICT, but not R\&D. In fact, the dummy for online procedures and the share of firms investing in ICT are only included in the ICT decision. Finally, following the idea that ICT investment is intensive in skilled workers (Bresnahan, Brynjolfsson, and Hitt, 2002), the ICT investment equation includes a human capital variable that is not introduced in the R\&D equation.

For Chilean firms, including all firms in the sample and for the services sector as well, we find a positive relationship between ICT investment and the introduction of technological and nontechnological innovations. Figures 1 and 2 show the probability of introducing innovation for firms that invest above and below the average ICT investment in their respective industries. The evidence shows that introducing innovations is more likely for firms that invest above the average. 


\subsection{Productivity Function}

We estimate the impact of innovation on productivity using the following specification:

$$
y=\alpha I_{i}^{*}+\beta k_{i}+\epsilon_{i}
$$

where y is labor productivity (log of real sales per worker), k is log of capital per worker, and I* is some of the predicted probabilities of innovation from the previous estimation.

As additional covariates for explaining productivity, we include the size of the firms. Given that we include capital per worker as a control variable, we interpret the parameters associated with innovation outcomes as the impact on total factor productivity (TFP). Given that we have information for two rounds of the survey, we allow lagged effects of innovation on productivity. All variables for investment and innovation are for 2007, and we measure productivity with information from 2009.

For identification purposes, we require some variables affecting innovation, but not affecting productivity. In this case, following the literature about technological spillovers (Feldman, 1999), we include the percentage of firms that innovate in the same region and sector, with the assumption that a higher presence of innovators should increase the firm's probability of innovation, but not productivity.

\section{Main Results}

This section discusses the estimation results for all firms in the sample. We first present the results for the R\&D and ICT investment models (Table 4) and then for innovation and productivity (Table 5). Table 4 shows that size is important for the decision of investing in both R\&D and ICT, and that larger firms are more likely to invest in each case. The results also indicate that the effect of being an exporter firm is positive for probabilities of investment in both R\&D and ICT, and that foreign firms are more likely to invest in ICT, but not in R\&D. In the case of ICT, the additional variables included in the estimation are both positive and significant, showing that online procedures and the prevalence of other firms investing in ICT increase the probability of firm ICT investment. 
With respect to the intensity equations (ICT and R\&D investment per worker, in logs), exporting appears to be positively correlated with higher R\&D and ICT investments. Also, foreign firms invest more in ICT, but not in R\&D. Our results show that public financial support is not positively correlated with the investment in either of the two. Finally, our findings for human capital confirm the expected positive impact of this variable on ICT investment.

Table 5 presents the estimation results for the innovation production function, where we use both the predicted investment in R\&D and ICT—estimated in the first stage-as explanatory variables for the innovation probability. Our results suggest that R\&D and ICT investments have a positive and significant effect on both indicators of innovation. The results for all other variables are similar across innovations indicators. We find that larger firms are more likely to innovate, but exporter and foreign firms are less likely to introduce innovations. The evidence is, in general, consistent with the existence of innovation spillovers, because the higher prevalence of innovators in the region and sector increases the probability of introducing innovations. This is true for both innovation indicators.

Table 6 shows the econometric results for the productivity function. To deal with endogeneity problems, we use the predicted values innovations obtained from the second-stage estimations. Our findings across specification with alternative measures of innovation indicate that this activity has positive and significant effect on total factor productivity. As expected, the results present a positive parameter for capital per worker, indicating that capital deepening increases labor productivity. In contrast, controlling for innovation and capital per worker, larger firms appear to be less productive. The last two columns of Table 6 introduce the predicted value of investment in ICT as an explanatory variable to test whether it influences productivity directly. The results indicate that innovation variables are not significant, but ICT investment has a positive and significant effect on productivity. This would suggest that ICT investment has a positive and direct impact on productivity and not indirectly through its impact on innovation. However, given that ICT and innovation are highly related, 
it is hard to push this result strongly. One could argue that these findings reveal how hard is to disentangle the direct and indirect effects of ICT investment on productivity.

\section{Results for the Services Sector}

Innovation in the services sector has been a relatively unexplored topic, in particular compared with innovation in the manufacturing sector. ${ }^{9}$ The main reason for the scarce evidence about services industry is because many researchers do not consider services as an innovative sector but rather as a user of technologies developed elsewhere (Gallouj and Savona, 2009; Tether and Howells, 2007). Studies on services firms are interesting because the determinants of innovation and R\&D may be different than those in other industries. Some studies have analyzed firm-level evidence on innovation in services and manufacturing industries, concluding that services sector is as innovative as the manufacturing sector. Indeed, part of this sector is also significantly tradable and subject to the potential benefits coming from international competition. ${ }^{10}$

Tether (2005), using information for several European countries, finds that services firms do in fact innovate, although the propensity to innovate technologically is lower than in manufacturing firms. Tether finds some differences in the innovation orientation of services firms; for example, they are more likely to innovate in organization change than firms in the manufacturing industry. However, he concludes that there is no unique pattern of innovation among firms in this sector. ${ }^{11}$ In addition, previous empirical evidence indicates that productivity is low in the services sector in Latin American countries when compared with productivity in more developed countries, and the economic importance of this sector has been growing in recent decades (Pagés, 2010). Accordingly, it is relevant in these countries to study how ICT may help to close the productivity gap with rich countries in the

\footnotetext{
9 An exception in developing countries is Crespi, Tacsir, and Vargas (2014).

10 See, for example, Zahler, lacovone, and Mattoo (2013).

${ }^{11}$ See also Pires, Sarkar, and Carvalho (2008) and Santamaria, Nieto, and Miles (2012) for further evidence.
} 
services industry. Moreover, some studies have found that ICT investment may be more relevant for innovation than R\&D investment in this sector (Polder et al., 2009).

Table 7 shows the regressions for the determinants of R\&D and ICT investments, revealing a positive impact of exporting on R\&D investment intensity and on the probability of investing in ICT. In contrast, foreign ownership of firms does not affect any of the investment variables. Similar to the findings for the total sample, larger firms are more likely to invest in both R\&D and ICT. In the particular case of ICT investment, and similar to previous results, we find that a higher proportion of skilled workers increases the investment intensity, and that on-line procedures and a higher adoption rate from other firms increase the probability of ICT investment.

Table 8 presents results for the second-stage regressions, looking at the relationship between investment in both R\&D and ICT and innovation outcomes. In contrast with the results considering the total sample, we find that R\&D does not have a significant effect on innovation for firms in the services sector. However, ICT investment has a positive and significant effect on both indicators of innovations. The evidence also shows that large firms are more likely to innovate, but the effects of exporting and foreign ownership on innovation are not robust.

Table 9 shows the results for the impact of innovation on productivity. The results are consistent with previous empirical evidence for all firms in the sample and other countries, showing that innovation has a positive impact on productivity. This is true for both innovation indicators. Further examining the potential indirect effect of ICT investment, the evidence suggests that ICT dominates the impact of innovation. When this variable-in its predicted value-is introduced in the estimation, the innovation variables turn out to be not significant.

In summary, the services sector does not appear to be different from the rest of the economy in terms of the relationship of ICT investment with innovation and productivity. Our results show that ICT investment in this sector increases the probability of introducing innovations and that these 
innovations increase firm productivity. More important, ICT investment, rather than R\&D investment, would be more relevant to increase productivity in the services industries.

\section{Conclusions}

Developing countries face the enormous challenge of closing the productivity gap with rich countries. According to previous studies, this is especially relevant for firms in the services sector, which, albeit its growing importance in the economy, still has a large productivity gap with other sectors. Given that ICT investment can help close this gap by increasing innovation and productivity, we study this issue using a sample of Chilean firms covering a wide range of industries, particularly in the services sector. Previous literature has mainly focused on the impact of R\&D investment and few works have investigated how both R\&D and ICT affect innovation in a developing country context. In fact, as the Chilean case demonstrates, the percentage of firms investing in ICT is substantially larger than that of firms investing in R\&D; thus, it seems plausible that investment in ICT may be a more relevant driver of innovation in this context.

Our results illustrate how ICT investment can contribute to closing this gap. In fact, in all of our estimations, we find that ICT enhances innovation outcomes, independent of the innovation measures and industries considered. Moreover, our results suggest that innovation variables are not significant when ICT investment is included in the productivity equation. Nevertheless, given that ICT investment and innovation outcomes are highly correlated, it is important to consider these results carefully. Our interpretation is that these findings reveal how hard is to disentangle the direct and indirect effects of ICT investment.

Our empirical analysis reveals some differences in terms of determinants and effects of ICT and R\&D investments in the services industries. Similar to Polder et al. (2009), which uses information for Dutch firms, our results indicate that ICT investment is more important than R\&D investment in the services sector. In fact, R\&D is not a significant determinant of innovation in services industries. This is 
interesting evidence when considering which type of investment should highlighted for enhancing innovation and productivity in services.

Regarding the determinants of ICT, our results reveal the importance of firm size, human capital, experience with online procedures, and potential externalities in the adoption of ICT. In contrast, public support is not associated with higher ICT investment, casting doubt on how public programs have contributed in this respect. More research is needed to uncover how these programs may be associated with investment in ICT to increase innovation and productivity in services. 
Table 1. Number of Firms and Sectoral Distribution

\begin{tabular}{lcc}
\hline Sector & $\mathrm{n}$ & $\%$ \\
\hline Agriculture & 158 & 6 \\
Mining & 130 & 5 \\
Manufacturing & 357 & 13 \\
Utilities & 78 & 3 \\
Construction & 261 & 10 \\
Retail & 613 & 23 \\
Hotel and restaurants & 270 & 10 \\
Transportation and communications & 271 & 10 \\
Financial services & 100 & 4 \\
Real estate & 284 & 11 \\
Community services & 145 & 5 \\
Total & 2,667 & 100 \\
\hline \multicolumn{1}{c}{ Source: Author's elaboration based on the ELE, 2007 and 2009.}
\end{tabular}


Table 2. Descriptive Statistics: ICT, R\&D, Innovation, and Productivity

\begin{tabular}{|c|c|c|c|c|c|c|}
\hline & \multicolumn{3}{|c|}{ All sectors } & \multicolumn{3}{|c|}{ Services } \\
\hline & Obs & Mean & St. Dev. & Obs & Mean & St. Dev. \\
\hline $\mathrm{ICT}>0$ & 2,667 & $29.2 \%$ & $45 \cdot 5 \%$ & 1,683 & $28.8 \%$ & $45 \cdot 3 \%$ \\
\hline $\mathrm{ICT} / \mathrm{L} *$ & 763 & 3,995 & 58,654 & 474 & 4,860 & 71,603 \\
\hline$R \& D>0$ & 2,667 & $2.2 \%$ & $14.7 \%$ & 1,683 & $1.4 \%$ & $11.6 \%$ \\
\hline$R \& D / L *$ & 58 & 3,610 & 9,787 & 22 & 3,397 & 7,928 \\
\hline Technological innovation & 2,667 & $41.6 \%$ & $49 \cdot 3 \%$ & 1,683 & $40.5 \%$ & $49.1 \%$ \\
\hline Any innovation & 2,667 & $45 \cdot 7 \%$ & $49.8 \%$ & 1,683 & $44.6 \%$ & $49.7 \%$ \\
\hline Non-technological innovation & 2,667 & $26.1 \%$ & $43.9 \%$ & 1,683 & $25 \cdot 3 \%$ & $43 \cdot 5 \%$ \\
\hline Productivity (sales per worker)** & 2,401 & 750,452 & 960,2170 & 1,527 & 650,995 & $9,258,590$ \\
\hline
\end{tabular}


Table 3. Descriptive Statistics: Firm Characteristics

\begin{tabular}{|c|c|c|c|c|c|c|}
\hline & \multicolumn{3}{|c|}{ All sectors } & \multicolumn{3}{|c|}{ Services } \\
\hline & Obs & Mean & St. Dev. & Obs & Mean & St. Dev. \\
\hline Exporter & 2,667 & $11.9 \%$ & $32.4 \%$ & 1,683 & $9.5 \%$ & $29.3 \%$ \\
\hline Foreign & 2,667 & $7.4 \%$ & $26.2 \%$ & 1,683 & $7.3 \%$ & $26.0 \%$ \\
\hline Public support & 2,666 & $17 \cdot 3 \%$ & $37.8 \%$ & 1,682 & $15 \cdot 5 \%$ & $36.2 \%$ \\
\hline Human capital & 2,266 & $14.7 \%$ & $23 \cdot 5 \%$ & 1,394 & $17.1 \%$ & $25.8 \%$ \\
\hline Size (total workers) & 2,667 & 215 & 850 & 1,683 & 204 & 877 \\
\hline Online & 2,667 & $85.7 \%$ & $35.0 \%$ & 1,683 & $85.1 \%$ & $35.6 \%$ \\
\hline Capital per worker & 2,407 & 531,963 & $8,736,586$ & 1,488 & 201,547 & $1,921,371$ \\
\hline
\end{tabular}
Source: Author's elaboration based on the ELE, 2007 and 2009.

Note: Capital per worker is measured in U.S. dollars, converted using an exchange rate from June of 2009. 
Table 4. R\&D and ICT Investment: All Firms

\begin{tabular}{|c|c|c|c|c|}
\hline Variables & $\begin{array}{c}\text { Intensity } \\
\text { R\&D } \\
\text { (log of R\&D } \\
\text { investment per } \\
\text { worker) }\end{array}$ & $\begin{array}{l}\text { Selection } \\
\text { R\&D }\end{array}$ & $\begin{array}{c}\text { Intensity } \\
\text { ICT } \\
\text { (log of ICT } \\
\text { investment } \\
\text { per worker) }\end{array}$ & $\begin{array}{l}\text { Selection } \\
\text { ICT }\end{array}$ \\
\hline Exporter & $\begin{array}{l}1.954^{* *} \\
(0.859)\end{array}$ & $\begin{array}{l}0.0191 * \\
(0.00984)\end{array}$ & $\begin{array}{l}0.387^{* *} \\
(0.162)\end{array}$ & $\begin{array}{l}0.0563 * \\
(0.0326)\end{array}$ \\
\hline Foreign & $\begin{array}{c}1.312 \\
(0.840)\end{array}$ & $\begin{array}{l}-0.00238 \\
(0.00513)\end{array}$ & $\begin{array}{l}0.403^{* *} \\
(0.185)\end{array}$ & $\begin{array}{c}0.119 * * * \\
(0.0408)\end{array}$ \\
\hline Public support & $\begin{array}{l}0.428 \\
(0.555)\end{array}$ & & $\begin{array}{c}0.153 \\
(0.146)\end{array}$ & \\
\hline Human capital & & & $\begin{array}{c}1.969 * * * \\
(0.331)\end{array}$ & \\
\hline Size & & $\begin{array}{c}0.00584 * * * \\
(0.00106)\end{array}$ & & $\begin{array}{c}0.0875^{* * *} \\
(0.00591)\end{array}$ \\
\hline On-line & & & & $\begin{array}{c}0.186 * * * \\
(0.0261)\end{array}$ \\
\hline ICT sector-region & & & & $\begin{array}{c}1.105^{* * *} \\
(0.125)\end{array}$ \\
\hline Constant & $\begin{array}{l}-1.219 \\
(2.959)\end{array}$ & & $\begin{array}{c}0.259 \\
(1.302)\end{array}$ & \\
\hline Observations & 2,427 & 2,427 & 2,393 & 2,393 \\
\hline
\end{tabular}

Source: Author's elaboration based on the ELE, 2007 and 2009.

Notes: All regressions incorporate sector fixed effects at the 1 digit level. For services, given that we have few observations for industries, we include a dummy variable for the KIBS (Knowledge Intensive Business Sector) and traditional services. Robust standard errors in parentheses. $* * * p<0.01, * *$ $\mathrm{p}<0.05, * \mathrm{p}<0.1$. 
Table 5. Innovation Outcome: All Firms

\begin{tabular}{lcc}
\hline Variables & Technological innovation & Any innovation \\
\hline Predicted R\&D investment & $0.181 * *$ & $0.206 * * *$ \\
& $(0.0730)$ & $(0.0750)$ \\
Predicted ICT investment & $0.0945^{* * *}$ & $0.0896 * * *$ \\
& $(0.0269)$ & $(0.0274)$ \\
Exporter & $-0.302 * * *$ & $-0.318 * * *$ \\
& $(0.103)$ & $(0.116)$ \\
Foreign & $-0.256 * * *$ & $-0.317^{* * *}$ \\
& $(0.0763)$ & $(0.0772)$ \\
Size & $0.0794 * * *$ & $0.0815^{* * *}$ \\
& $(0.00675)$ & $(0.00691)$ \\
Innovation sector \& region & $1.401 * * *$ & $1.332 * * *$ \\
& $(0.118)$ & $(0.119)$ \\
Observations & 2,265 & 2,265 \\
\hline
\end{tabular}

Source: Author's elaboration based on the ELE, 2007 and 2009.

Notes: Robust standard errors in parentheses. $* * * p<0.01, * * p<0.05, * p<0.1$. The predicted R\&D and predicted ICT investments are those calculated from estimations presented in Table 4. 
Table 6. Productivity Function: All Firms

\begin{tabular}{lcccc}
\hline Variables & $(1)$ & $(2)$ & $(3)$ & $(4)$ \\
\hline Predicted tech innovation & $0.695^{* * *}$ & & -0.120 & \\
& $(0.222)$ & & $(0.221)$ & \\
Predicted any innovation & & $0.838 * * *$ & & -0.0168 \\
& & $(0.231)$ & & $(0.230)$ \\
Predicted ICT & & & $0.653^{* * *}$ & $0.644^{* * *}$ \\
& & & $(0.0786)$ & $(0.0790)$ \\
Capital per worker & $0.277^{* * *}$ & $0.276 * * *$ & $0.237^{* * *}$ & $0.237^{* * *}$ \\
& $(0.0186)$ & $(0.0185)$ & $(0.0175)$ & $(0.0174)$ \\
Size & $-0.0929 * * *$ & $-0.107^{* * *}$ & $-0.0454 *$ & $-0.0532 * *$ \\
& $(0.0259)$ & $(0.0281)$ & $(0.0245)$ & $(0.0267)$ \\
Constant & $14.03 * * *$ & $13.99 * * *$ & $14.29 * * *$ & $14.27^{* * *}$ \\
& $(0.315)$ & $(0.317)$ & $(0.309)$ & $(0.310)$ \\
Observations & 2,017 & 2,017 & 2,017 & 2,017 \\
R-squared & 0.307 & 0.308 & 0.340 & 0.340 \\
\hline
\end{tabular}

Source: Author's elaboration based on the ELE, 2007 and 2009.

Notes: Robust standard errors in parentheses. $* * * p<0.01, * * p<0.05, * p<0.1$. The tech and any innovation variables are those calculated from estimations presented in Table 5. 
Table 7. R\&D and ICT Investment: Services

\begin{tabular}{|c|c|c|c|c|}
\hline Variables & $\begin{array}{c}\text { Intensity } \\
\text { R\&D } \\
\text { (log of R\&D } \\
\text { investment } \\
\text { per worker) }\end{array}$ & $\begin{array}{l}\text { Selection } \\
\text { R\&D }\end{array}$ & $\begin{array}{c}\text { Intensity } \\
\text { ICT } \\
\text { (log of ICT } \\
\text { investment per } \\
\text { worker) } \\
\end{array}$ & $\begin{array}{l}\text { Selection } \\
\text { ICT }\end{array}$ \\
\hline Exporter & $\begin{array}{l}2.279 * * \\
(0.908)\end{array}$ & $\begin{array}{c}0.0127 \\
(0.00944)\end{array}$ & $\begin{array}{c}0.159 \\
(0.200)\end{array}$ & $\begin{array}{l}0.122 * * * \\
(0.0454)\end{array}$ \\
\hline Foreign & $\begin{array}{c}0.395 \\
(1.092)\end{array}$ & $\begin{array}{l}-0.00221 \\
(0.00541)\end{array}$ & $\begin{array}{c}0.308 \\
(0.224)\end{array}$ & $\begin{array}{c}0.0688 \\
(0.0478)\end{array}$ \\
\hline Public support & $\begin{array}{c}2.234 * * * \\
(0.736)\end{array}$ & & $\begin{array}{c}0.277 \\
(0.196)\end{array}$ & \\
\hline Human capital & & & $\begin{array}{c}2.017^{* * *} \\
(0.320)\end{array}$ & \\
\hline Size & & $\begin{array}{c}0.00448 * * * \\
(0.00106)\end{array}$ & & $\begin{array}{c}0.0879 * * * \\
(0.00763)\end{array}$ \\
\hline On-line & & & & $\begin{array}{l}0.230 * * * \\
(0.0274)\end{array}$ \\
\hline ICT sector-region & & & & $\begin{array}{c}0.793^{* * *} \\
(0.118)\end{array}$ \\
\hline Constant & $\begin{array}{l}-0.197 \\
(2.823)\end{array}$ & & $\begin{array}{l}2.765^{* *} \\
(1.104)\end{array}$ & \\
\hline Observations & 1,502 & 1,502 & 1,480 & 1,480 \\
\hline
\end{tabular}

Source: Author's elaboration based on the ELE, 2007 and 2009.

Notes: Robust standard errors in parentheses. *** $p<0.01, * * p<0.05, * p<0.1$. 
Table 8. Innovation Outcome: Services

\begin{tabular}{lcc}
\hline Variables & Technological innovation & Any innovation \\
\hline Predicted R\&D investment & 0.00265 & 0.00919 \\
& $(0.0185)$ & $(0.0191)$ \\
Predicted ICT investment & $0.0735^{* *}$ & $0.0604^{* *}$ \\
& $(0.0288)$ & $(0.0292)$ \\
Exporter & 0.0878 & $0.134^{* *}$ \\
& $(0.0669)$ & $(0.0673)$ \\
Foreign & -0.0369 & -0.0693 \\
& $(0.0544)$ & $(0.0555)$ \\
Size & $0.0782^{* * *}$ & $0.0777^{* * *}$ \\
& $(0.00840)$ & $(0.00859)$ \\
Innovation sector and region & $1.039 * * *$ & $1.034^{* * *}$ \\
Observations & $(0.135)$ & $(0.136)$ \\
\hline
\end{tabular}

Source: Author's elaboration based on the ELE, 2007 and 2009.

Notes: Robust standard errors in parentheses. $* * * p<0.01, * * p<0.05, * p<0.1$. The predicted R\&D and predicted ICT investments are those calculated from estimations presented in Table 7. 
Table 9. Productivity: Services

\begin{tabular}{lcccc}
\hline Variables & $(1)$ & $(2)$ & $(3)$ & $(4)$ \\
& & & & \\
\hline Predicted tech innovation & $2.043^{* * *}$ & & 0.672 & \\
& $(0.416)$ & & $(0.461)$ & \\
Predicted any innovation & & $1.836 * * *$ & & 0.636 \\
& & $(0.398)$ & & $(0.428)$ \\
Predicted ICT & & & $0.556 * * *$ & $0.565 * * *$ \\
& & & $(0.0915)$ & $(0.0888)$ \\
Capital per worker & & & $0.236 * * *$ & $0.236 * * *$ \\
& $(0.0225)$ & $(0.0225)$ & $(0.0212)$ & $(0.0212)$ \\
Size & $-0.229 * * *$ & $-0.214 * * *$ & $-0.133^{* * *}$ & $-0.131 * * *$ \\
& $(0.0411)$ & $(0.0406)$ & $(0.0428)$ & $(0.0417)$ \\
Constant & $14.79 * * *$ & $14.76 * * *$ & $13.75 * * *$ & $13.70 * * *$ \\
& $(0.361)$ & $(0.362)$ & $(0.410)$ & $(0.412)$ \\
Observations & 1,245 & 1,245 & 1,245 & 1,245 \\
R-squared & 0.184 & 0.181 & 0.212 & 0.212 \\
\hline
\end{tabular}

Source: Author's elaboration based on the ELE, 2007 and 2009.

Notes: Robust standard errors in parentheses. $* * * p<0.01, * * p<0.05, * p<0.1$. The tech and any innovation variables are those calculated from estimations presented in Table 5. 
Figure 1. ICT Investment and Technological and Non-technological Innovation: All Firms

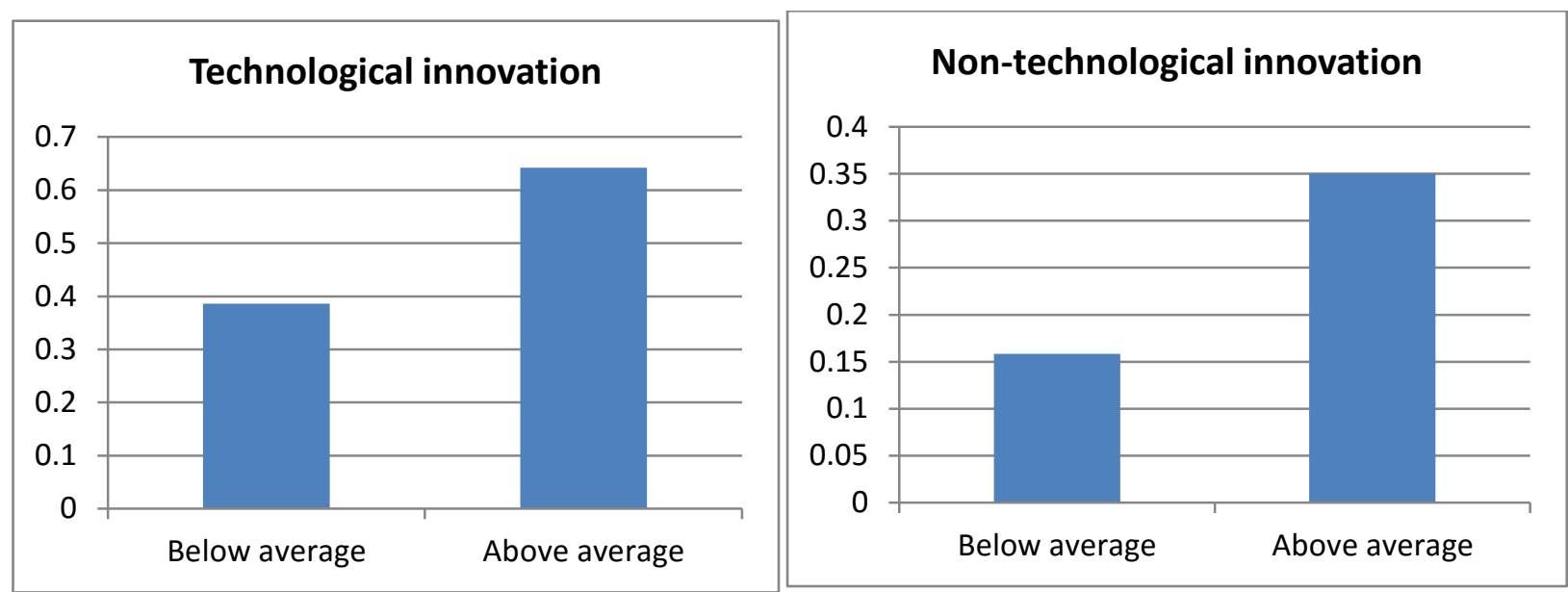

Source: Author's elaboration based on Longitudinal Enterprise Survey. 
Figure 2. ICT Investment and Technological and Non-technological Innovation: Services

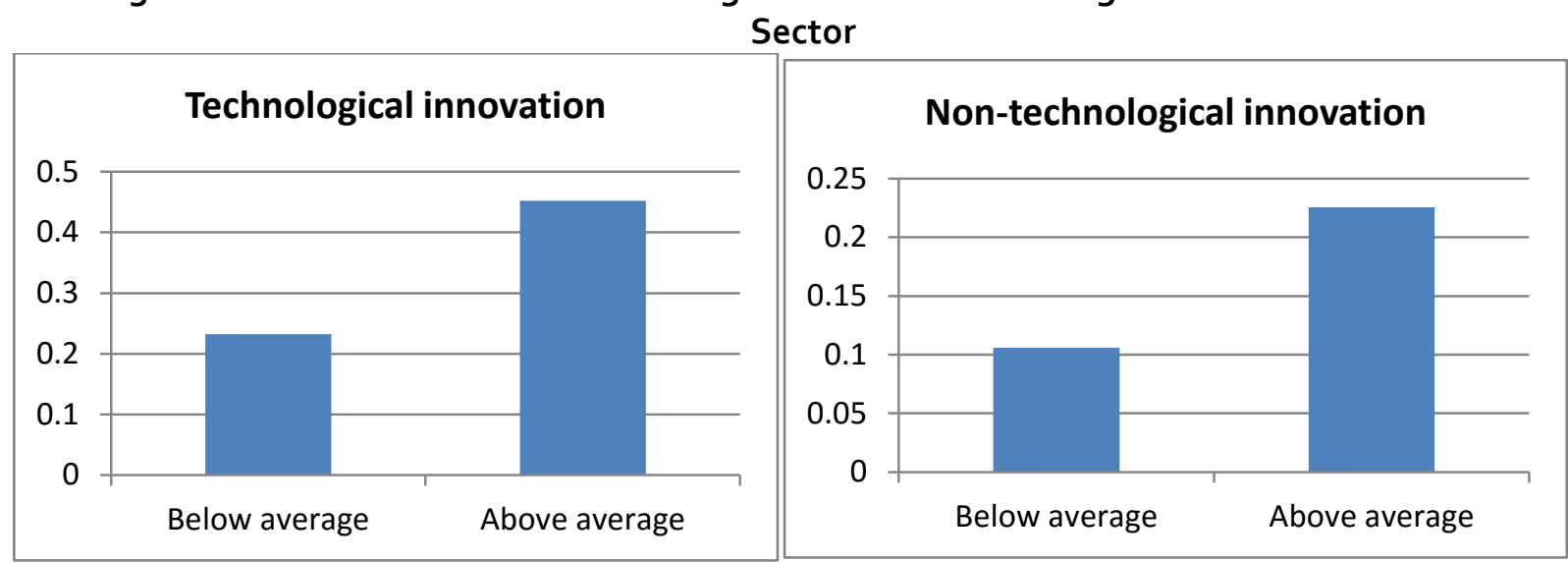

Source: Author's elaboration based on Longitudinal Enterprise Survey. 


\section{References}

Aboal, D and E. Tacsir. 2015. "Innovation and Productivity in Services and Manufacturing: The Role of ICT Investment (No. 012)." United Nations University-Maastricht Economic and Social Research Institute on Innovation and Technology (MERIT).

Acemoglu, D., D Dorn, G. H. Hanson, and B. Price. 2014. "Return of the Solow Paradox? IT, Productivity, and Employment in US Manufacturing." The American Economic Review 104(5): 394-99.

Álvarez, R., C. Bravo-Ortega, and L. Navarro. 2010. "Innovation, R\&D Investment and Productivity in Chile." IDB Working Paper No. IDB-WP-19o. Washington, DC: Inter-American Development Bank.

Álvarez, R., A. Zahler, and C. Bravo-Ortega. 2012. "Innovation and Productivity in Services: Evidence from Chile." IDB Discussion Paper No. IDB-DP-263, Washington, DC: Inter-American Development Bank

Benavente, J. M. 2006. "The Role of Research and Innovation in Promoting Productivity in Chile." Economics of Innovation and New Technology 15(4-5): 301-15.

Black, S. E. and L. M. Lynch. 2001. "How to Compete: The Impact of Workplace Practices and Information Technology on Productivity." Review of Economics and Statistics 83(3): 434-45.

Bresnahan, T. F., E. Brynjolfsson, and L. M. Hitt. 2002. "Information Technology, Workplace Organization, and the Demand for Skilled Labor: Firm-Level Evidence." Quarterly Journal of Economics 117: 339-76.

Bugamelli, M. and P. Pagano. 2004. "Barriers to Investment in ICT." Applied Economics 36(20): 2275-86.

Cardona, M., T. Kretschmer, and T. Strobel. 2013. "ICT and Productivity: Conclusions from the Empirical Literature." Information Economics and Policy 25(3): 109-25.

Commander, S., R. Harrison, and N. Menezes-Filho. 2011. "ICT and Productivity in Developing Countries: New Firm-level Evidence from Brazil and India." Review of Economics and Statistics 93(2): 528-41.

Crépon, B., E. Duguet, and J. Mairesse. 1998. "Research, Innovation and Productivity: An Econometric Analysis at the Firm Level." Economic of Innovation and New Technology 7(2): 115-58.

Crespi, G., E. Tacsir, and F. Vargas. 2014. "Innovation and Productivity in Services: Empirical Evidence from Latin America." IDB Technical Note No. IDB-TN-69o. Washington, DC: Inter-American Development Bank. 
Crespi, G. and P. Zúñiga. 2012. "Innovation and Productivity: Evidence from Six Latin American Countries." World Development 40(2): 273-90.

Feldman, M. 1999. "The New Economics of Innovation, Spillovers and Agglomeration: A Review of Empirical Studies." Economics of Innovation and New Technology 8: 5-25.

Gallego, J. M., L. H. Gutiérrez, and S. H. Lee. 2015. "A Firm-level Analysis of ICT Adoption in an Emerging Economy: Evidence from the Colombian Manufacturing Industries." Industrial and Corporate Change 24(1): $191-221$.

Gallouj, F. and M. Savona. 2009. "Innovation in Services: A Review of the Debate and a Research Agenda." Journal of Evolutionary Economics 19(2): 149-72.

Greenan, N. and J. Mairesse. 2000. "Computers and Productivity in France: Some Evidence." Economics of Innovation and New Technology 9(3): 275-315.

Griffith, R., E. Huergo, J. Mairesse, and B. Peters. 2006. "Innovation and Productivity across Four European Countries." Oxford Review of Economic Policy 22(4): 483-98.

Hall, B. H., F. Lotti, and J. Mairesse. 2009. "Innovation and Productivity in SMEs: Empirical Evidence for Italy." Small Business Economics 33(1): 13-33.

- 2013. "Evidence on the Impact of R\&D and ICT Investments on Innovation and Productivity in Italian Firms." Economics of Innovation and New Technology 22(3): 300-28.

Hempell, T. and T. Zwick. 2008. "New Technology, Work Organisation and Innovation." Economics of Innovation and New Technology 17 (4): 331-54.

Higón, D. A. 2012. "The Impact of ICT on Innovation Activities: Evidence for UK SMEs." International Small Business Journal 30(6): 684-99.

Koellinger, P. 2008. "The Relationship between Technology, Innovation, and Firm Performance-Empirical Evidence from E-business in Europe." Research Policy 37(8): 1317-28.

Mairesse J, and P. Mohnen. 2010. "Using Innovation Surveys for Econometric Analysis. " In B. H. Hall and N. Rosenberg (eds.), Handbook of the Economics of Innovation, Vol. 2. North Holland: Elsevier.

Morikawa, M. 2004. "Information Technology and the Performance of Japanese SMEs." Small Business Economics 23(3): 171-77. 
Pagés, C. (editor). 2010. The Age of Productivity: Transforming Economies from the Bottom Up. Washington, DC: Inter-American Development Bank and Palgrave Macmillan.

Pires, C. P., S. Sarkar, and L. Carvalho. 2008. "Innovation in Services-How Different from Manufacturing?" The Service Industries Journal 28(10): 1339-56.

Polder, M., G. V. Leeuwen, P. Mohnen, and W. Raymond. 2009. "Productivity Effects of Innovation Modes." Unpublished.

Santamaría, L., M. Nieto, and I. Miles. 2012. "Service Innovation in Manufacturing Firms: Evidence from Spain." Technovation 32(2): 144-55.

Solow, R. M. 1987. "We'd Better Watch Out." A review of Manufacturing Matters: The Myth of the Post-Industrial Economy, by S. S. Cohen and J. Zysman. New York Times, July 12, 1987.

Tether, B. 2005. "Do Services Innovate (Differently)? Insights from the European Innobarometer Survey." Industry and Innovation 12(2): 153-84.

Tether, B. and J. Howells. 2007. "Changing Understanding of Innovation in Services." Innovation in Services 9: 2160.

Zahler, A., L. lacovone, and A. Mattoo. 2014. "Trade and Innovation in Services: Evidence from a Developing Economy." The World Economy 37(7): 953-79. 